\title{
Development and Optimization of a Floating Multiparticulate Drug Delivery System for Norfloxacin
}

\author{
Norfloksasin için Yüzen Çok Partiküllü Bir İlaç Salım Sisteminin \\ Geliştirilmesi ve Optimizasyonu
}

\author{
(D) Vaibhav SALVE, (D) Rakesh MISHRA*, (D) Tanaji NANDGUDE \\ Dr. D.Y. Patil Institute of Pharmaceutical Science and Research, Department of Pharmaceutics, Maharashtra, India
}

\begin{abstract}
Objectives: Norfloxacin is a synthetic broad-spectrum antibacterial drug having poor bioavailability and pH-dependent solubility. The purpose of the present study was to develop a gastroretentive floating multiparticulate drug delivery system for norfloxacin.

Materials and Methods: Norfloxacin core pellets were prepared using microcrystalline cellulose (MCC) and polyvinylpyrrolidone K30 (PVP K30) by extrusion and spheronization. A 3-level, 3-factor, 17-run experimental Box-Behnken design was adopted to optimize levels of variables in the pellets' formulations. The selected independent variables were amounts of MCC and PVP K30 and spheronizing speed and the dependent variables were aspect ratio and hardness of pellets. Sodium bicarbonate and hydroxypropyl methylcellulose K15M in the ratios of 1:1, 1:2, and 2:1 (w/w) on a dry solid basis were incorporated into the norfloxacin pellets and they were further coated with Eudragit RL 100 using a fluidized bed processor to obtain weight gain of $5 \%, 10 \%$, and $15 \% \mathrm{w} / \mathrm{w}$. The fourier transform infrared spectrum, scanning electron microscopy, physical characterization, particle size distribution analysis, floating studies, and in vitro drug release studies of the pellets were evaluated.

Results: Among the floating multiparticulate pellets batches, batch B-22 was found to be optimized based on the criteria of attaining the minimum floating lag time ( $<10 \mathrm{~min}$ ) and the maximum value of drug released $82.11 \%$ in $8 \mathrm{~h}$. The percentage drug release for batches B-21 and B-23 was $91.12 \%$ in $5 \mathrm{~h}$ and $60.67 \%$ in $8 \mathrm{~h}$, respectively. The drug release studies indicated that as the Eudragit RL 100 polymer coat increases the drug release decreases, producing sustained release of norfloxacin. The floating studies revealed that $70 \%-90 \%$ of pellets remained floating for up to $8 \mathrm{~h}$. All the batches have excellent flow properties with angle of repose in the range of $25.5 \pm 0.49^{\circ}$ to $28.02 \pm 0.30^{\circ}$, and Carr's index and Hausner's ratio in the range of $5 \%$ to $15 \%$ and $1.05 \pm 0.3$ to $1.14 \pm 0.3$, respectively.

Conclusion: The significant outcome obtained in the study is that such an approach can be effectively employed for improvement of the bioavailability of drugs having poor absorption in the lower part of the gastrointestinal tract with enhanced therapeutic efficacy.
\end{abstract}

Key words: Gastroretentive, floating multiparticulate, norfloxacin, spheronization, Box-Behnken design

Öz

Amaç: Norfloksasin zayıf biyoyararlanımı olan ve pH'a bağlı çözünürlüğe sahip sentetik geniş spektrumlu bir antibakteriyel ilaçtır. Bu çalışmanın amacı, norfloksasin için gastroretentif bir yüzen çok partiküllü ilaç salım sistemi geliştirmektir.

Gereç ve Yöntemler: Norfloksasin çekirdek pelletleri, ekstrüzyon ve sferonizasyonla mikrokristalli selüloz (MCC) ve polivinilpirolidon K30 (PVP K30) kullanılarak hazırlanmıştır. Pelletlerin formülasyonlarındaki değişken seviyelerini optimize etmek için 3 seviyeli, 3 faktörlü, 17 çalıșma deneysel bir Boxn Behnken tasarımı benimsenmiştir. Seçilen bağımsız değişkenler, MCC ve PVP K30 miktarları ve sferonizasyon hızı ve bağımlı değişkenler, boyut oranı ve pelletlerin sertliği idi. Kuru katı bazda 1:1, 1:2 ve 2:1 (a/a) oranlarında sodyum bikarbonat ve hidroksipropil metilselüloz K15M norfloksasin peletlerine katılmış ve \%5, \%10 ve \%15 a/a ağırlık artışı elde etmek için akışkanlaştırılmış yatak kullanılarak Eudragit RL 100 ile kaplanmıştır. Fourier transform infrared spektrumu, taramalı elektron mikroskobu, fiziksel karakterizasyon, partikül büyüklüğü dağılım analizi, yüzme çalıșmaları ve pelletlerin in vitro etken madde salım çalışmaları değerlendirilmiştir.

Bulgular: Yüzen çok partikülü pelet partileri arasında, B-22 partisi minimum yüzme gecikme süresine ( $<10$ dakika) ve 8 saat içinde maksimum etken madde salım değeri \%82.11'e ulaşma kriterlerine dayanarak optimize edilmiştir. B-21 ve B-23 partileri için etken madde salım yüzdesi, sırasıyla 5

*Correspondence: E-mail: mishrarakesh287@gmail.com, Phone: +9579790159 ORCID-ID: orcid.org/0000-0002-8520-1412

Received: 27.04.2018, Accepted: 11.06.2018

๑Turk J Pharm Sci, Published by Galenos Publishing House. 
saatte \%91.12 ve 8 saatte \%60.67 idi. Etken madde salım çalışmaları, Eudragit RL 100 polimer kaplaması arttıkça, etken madde salınımının azaldığını ve sürekli olarak norfloksasin salımı sağladığını göstermiştir. Yüzme çalışmaları, pelletlerin \%70-90'ının 8 saate kadar yüzer şekilde kaldığını ortaya koymuştur. Tüm partiler, $25.5 \pm 0.49^{\circ}-28.02 \pm 0.30^{\circ}$ aralı̆̆ında yığın açısı ve sırasıyla \%5 ila \%15 ve $1.05 \pm 0.3$ ila $1.14 \pm 0.3$ aralığında Carr indeksi ve Hausner oranı ile mükemmel akış özelliklerine sahiptir.

Sonuç: Çalışmada elde edilen önemli sonuç, bu tür bir yaklaşımın, gastrointestinal sistemin alt kısmında zayıf bir şekilde absorpsiyonu olan ilaçların biyoyararlanımının arttırılması ve terapötik etkinliklerinin iyileștirilmesinde etkili bir şekilde kullanılabileceğidir.

Anahtar kelimeler: Gastroretentif, yüzen çok partiküllü ilaç salım sistemi, norfloksasin, sferonizasyon, Box-Behnken tasarımı

\section{INTRODUCTION}

The oral route plays an important role in therapy as it is the most preferred and convenient route for drug delivery systems.' Gastroretentive drug delivery systems (GRDDSs) are an advanced approach for the novel drug-delivery systems in which the drug is retained in the stomach for a prolonged period. ${ }^{2,3}$ GRDDSs are particularly suitable for drugs having a narrow absorption window, drugs that act locally in a part of the gastrointestinal tract, drugs that are unstable in intestinal fluids, and drugs that exhibit poor solubility in the intestinal tract. $^{4}$

Floating drug delivery systems (FDDSs) are one of the most prominent approaches of GRDDs, characterized by the capacity of the formulation to float in and over the gastric contents. FDDSs are low density systems, which allows them to remain buoyant in the stomach for a prolonged period. In the development of FDDSs based on the mechanism of buoyancy the widely employed technology is effervescent systems. In effervescent systems, carbon dioxide gas production occurs due to the reaction of carbonates and bicarbonates present in the formulation with gastric fluid. The gas that forms is entrapped in the polymers, which allows the system to remain buoyant. The FDDSs are effectively used to design sustained drug delivery systems and improve the overall oral bioavailability of drugs. ${ }^{5-7}$

Norfloxacin is fluoroquinolone anti-infective antibacterial drug firstly used in the treatment of urinary tract infections, prostatitis, gonorrhea, and genital tract infections. ${ }^{8}$ It has $30 \%-40 \%$ bioavailability with a plasma half-life of 3 to $4 \mathrm{~h}$, thus requiring multiple dosing to maintain adequate plasma concentration during treatment. ${ }^{9}$ Norfloxacin is also poorly absorbed from the lower part of the gastrointestinal tract and it is well absorbed from the stomach. The solubility of norfloxacin in water is $\mathrm{pH}$-dependent, increasing sharply with decreasing $\mathrm{pH}$ below 5., 10,11

The therapeutic dose of norfloxacin is very high $(400 \mathrm{mg}$ orally twice daily) in the treatment of urinary tract infections. ${ }^{12}$ Many novel approaches have been reported that are used for bioavailability enhancement of norfloxacin, either directed towards the development of a single unit system or unable to produce a significant effect on improvement of bioavailability. Thus it was decided to develop a floating multiparticulate drug delivery system for norfloxacin that could produce sustained release so as to maintain drug plasma levels for improving bioavailability and therapeutic effects.

A floating multiparticulate system was developed in which norfloxacin pellets containing different ratios of sodium bicarbonate $\left(\mathrm{NaHCO}_{3}\right.$ ):hydroxypropyl methylcellulose (HPMC) K15M were prepared by extrusion spheronization. The pellets were coated with Eudragit RL 100 on a fluidized bed processor by the bottom spray technique. The amount of the effervescent agent and coating level of Eudragit RL 100 polymeric membrane were evaluated and optimized in terms of floating ability and drug release properties.

\section{MATERIALS AND METHODS}

\section{Materials}

Norfloxacin was a kind gift provided by Aarti Drugs Ltd, Mumbai, India. Eudragit RL 100 was provided by Evonik, Mumbai, India. All the other chemicals were used as received and were of analytical reagent grade.

\section{Preparation method for norfloxacin pellets}

\section{Extrusion and spheronization}

The norfloxacin core pellets were prepared using wet granulation by extrusion and spheronization. A powder mixture of norfloxacin and microcrystalline cellulose was mixed in a mortar for $20 \mathrm{~min}$. This was followed by addition of binding liquid consisting of 3\% polyvinylpyrrolidone K30 in water. The obtained wet mass was passed through BSS sieve no. 16 to get the extrudates. The prepared extrudates were then transferred to a spheronizer (Shakti Pharmatech, Ahmedabad, India) and spheronized at different spheronizing speeds to get pellets. The prepared core pellets were oven dried overnight at $60^{\circ} \mathrm{C}$.

\section{Experimental design}

A 3-level, 3-factor, 17-run experimental Box-Behnken design was adopted to optimize levels of variables in the pellet formulations. The selected independent variables were amount of MCC, i.e. microcrystalline cellulose (X1), PVP (K30), i.e. polyvinylpyrollidone (X2), and spheronizing speed (X3) as shown in Table 1. The dependent variables were aspect ratio (Y1) so as to predict the sphericity and hardness (Y2).The generation of experimental runs, ANOVA study and optimization were carried out by Design-expert ${ }^{\circledR}$ software 10 . The formulation batches prepared are indicated in (Table $2 \mathrm{a}$ ).

The optimized norfloxacin pellet batch in terms of sphericity and hardness was selected followed by incorporation of $\mathrm{NaHCO}_{3}$ and HPMC K15M in the ratios of 1:1, 1:2, and 2:1 (w/w) on a dry solid basis as indicated in Table $2 \mathrm{~b}$.

Coating of norfloxacin pellets containing $\mathrm{NaHCO}_{3}: \mathrm{HPMC} \mathrm{K15M}$ The norfloxacin pellets containing $\mathrm{NaHCO}_{3}: \mathrm{HPMC} \mathrm{K15M}$ in the ratio of 1:1 were further coated with Eudragit RL 100 using a 
fluidized bed processor (ACG, Miniquest-F, Mumbai, India) to obtain weight gain of $5 \%, 10 \%$, and $15 \% \mathrm{w} / \mathrm{w}$ as shown in Table $2 \mathrm{~b}$. The coating solution was prepared by dissolving the desired amount of Eudragit RL 100 in isopropyl alcohol and stirring to obtain a clear solution.

The layering conditions were as follows: batch size, $7.5 \mathrm{~g}$; inlet temperature, $40^{\circ} \mathrm{C}$; product temperature, $35^{\circ} \mathrm{C}$; air flow, 0.8-1.0 bar; spray pressure, 0.5-0.9 bar; spray rate, $0.130 \mathrm{~g} / \mathrm{min}$; and final drying at $40^{\circ} \mathrm{C}$ for $15 \mathrm{~min}$.

\section{Evaluation of floating norfloxacin pellets}

\section{Spectroscopic studies}

\section{Calibration curve of norfloxacin in $0.1 \mathrm{~N} \mathrm{HCl}$}

First $10 \mathrm{mg}$ of norfloxacin was accurately weighed and dissolved in $100 \mathrm{~mL}$ of $0.1 \mathrm{~N} \mathrm{HCl}$ in a volumetric flask to get

Table 1. Experimental design parameters

\begin{tabular}{lllllll} 
Factors & \multicolumn{3}{l}{$\begin{array}{l}\text { Levels used (coded } \\
\text { value) }\end{array}$} & \multicolumn{3}{l}{ Actual value (\%) } \\
\cline { 2 - 6 } & Low & Medium & High & Low & Medium & High \\
\hline $\begin{array}{l}\text { Microcrystalline } \\
\text { cellulose }\end{array}$ & -1 & 0 & +1 & 25 & 30 & 35 \\
\hline $\begin{array}{l}\text { Polyvinylpyrrolidone } \\
\text { K30 }\end{array}$ & -1 & 0 & +1 & 4 & 6 & 8 \\
\hline $\begin{array}{l}\text { Spheronizing speed } \\
\text { (rpm) }\end{array}$ & -1 & 0 & +1 & 750 & 850 & 950 \\
\hline
\end{tabular}

Table 2a. Composition of experimental formulations

\begin{tabular}{llll}
$\begin{array}{l}\text { Batch } \\
\text { number }\end{array}$ & $\begin{array}{l}\text { Microcrystalline } \\
\text { cellulose (\%) }\end{array}$ & $\begin{array}{l}\text { Polyvinylpyrrolidone } \\
\text { K30 (\%) }\end{array}$ & $\begin{array}{l}\text { Spheronizing speed } \\
\text { (rpm) }\end{array}$ \\
\hline B-1 & 25 & 4 & 850 \\
\hline B-2 & 35 & 6 & 750 \\
\hline B-3 & 30 & 6 & 850 \\
\hline B-4 & 35 & 6 & 950 \\
\hline B-5 & 30 & 6 & 850 \\
\hline B-6 & 35 & 8 & 850 \\
\hline B-7 & 25 & 8 & 850 \\
\hline B-8 & 30 & 4 & 950 \\
\hline B-9 & 35 & 4 & 850 \\
\hline B-10 & 30 & 6 & 850 \\
\hline B-11 & 30 & 6 & 850 \\
\hline B-12 & 30 & 6 & 850 \\
\hline B-13 & 30 & 8 & 750 \\
\hline B-14 & 25 & 6 & 750 \\
\hline B-15 & 25 & 6 & 950 \\
\hline B-16 & 30 & 450 \\
\hline B-17 & 30 & 8 & \\
\hline & & 6 & 750 \\
\hline
\end{tabular}

$100 \mu \mathrm{g} / \mathrm{mL}$ stock solution. This solution was further diluted with $0.1 \mathrm{~N} \mathrm{HCl}$ to get solutions in the concentration range of 1 to $10 \mu \mathrm{g} / \mathrm{mL}$. Absorbance of these solutions was determined spectrophotometrically (Shimadzu 1700, Japan) at $273 \mathrm{~nm} .^{13,14}$

\section{Fourier transform infrared spectrum}

The powder sample of norfloxacin, Eudragit RL 100, and physical mixture of norfloxacin and polymer (Eudragit RL 100) was kept in a dryer to make it moisture-free. The dry sample of powders was separately mixed and triturated with dry potassium bromide. This mixture was placed in a DRS assembly sample holder. The infrared spectrum was recorded and the spectral analysis was done (Shimadzu, 8400S, Japan). ${ }^{15}$

\section{Drug content}

Norfloxacin pellets equivalent to $400 \mathrm{mg}$ were ground using a mortar and pestle and transferred into a $50 \mathrm{~mL}$ volumetric flask containing $0.1 \mathrm{~N} \mathrm{HCl}$ and the volume was made up to $50 \mathrm{~mL}$. The mixture was sonicated for 10 min to ensure complete extraction of the drug. The solution was filtered through Whatman filter paper and assayed spectrophotometrically (Shimadzu 1700, Japan) at $273 \mathrm{~nm}$ to determine the percent drug content. 16,17

\section{In vitro drug release studies}

Drug release studies of the norfloxacin pellets were performed by USP Dissolution Apparatus-I (Veego DA-8D, India). The dissolution studies were carried out with $900 \mathrm{~mL}$ of 0.1 $\mathrm{N} \mathrm{HCl}$ as dissolution medium at $37 \pm 0.5^{\circ} \mathrm{C}$ and at $50 \mathrm{rpm}$. Pellets equivalent to $400 \mathrm{mg}$ of norfloxacin were weighed and transferred to the dissolution apparatus. A $10 \mathrm{~mL}$ aliquot was withdrawn and immediately replaced by the same volume of fresh medium to maintain sink condition. The aliquot was filtered through Whatman filter paper and absorbance was measured at $273 \mathrm{~nm}$ using a UV spectrophotometer (Shimadzu 1700 , Japan) to determine the drug release. ${ }^{16-18}$

\section{In vitro buoyancy studies ${ }^{19-21}$}

The time required for the pellets to rise to the surface and float as floating lag time and total duration of time for which pellets remain buoyant, i.e. total floating time, were determined. The

Table 2b. Composition of experimental formulations containing different ratios of $\mathrm{NaHCO}_{3}: \mathrm{HPMC} \mathrm{K15M}$ and Eudragit RL 100

$$
\text { coating }
$$

\begin{tabular}{|c|c|c|c|c|c|c|}
\hline \multirow[t]{2}{*}{ Ingredients (g) } & \multicolumn{6}{|c|}{ Batch number } \\
\hline & B-18 & B-19 & B-20 & B-21 & B-22 & B-23 \\
\hline Norfloxacin & 3.33 & 3.33 & 3.33 & 3.33 & 3.33 & 3.33 \\
\hline $\begin{array}{l}\text { Microcrystalline } \\
\text { cellulose }\end{array}$ & 1.27 & 1.27 & 1.27 & 1.27 & 1.27 & 1.27 \\
\hline $\begin{array}{l}\text { Polyvinylpyrrolidone } \\
\text { K30 }\end{array}$ & 0.3 & 0.3 & 0.3 & 0.3 & 0.3 & 0.3 \\
\hline Sodium bicarbonate & 1.25 & 0.83 & 1.66 & 1.25 & 1.25 & 1.25 \\
\hline $\begin{array}{l}\text { Hydroxypropyl } \\
\text { methylcellulose K15 }\end{array}$ & 1.25 & 1.66 & 0.83 & 1.25 & 1.25 & 1.25 \\
\hline $\begin{array}{l}\text { Eudragit RL } 100 \text { (\% } \\
\text { weight gain) }\end{array}$ & - & - & - & 5 & 10 & 15 \\
\hline
\end{tabular}


floating pellets (100) was kept in a USP Type-I dissolution apparatus, the dissolution medium used was $0.1 \mathrm{~N} \mathrm{HCl}$, and the conditions were $37 \pm 5^{\circ} \mathrm{C}$ at $50 \mathrm{rpm}$. The percentage of floating pellets was determined by the following equation:

Floating pellets $(\%)=\frac{\text { number of floating pellets at measuring time }}{\text { initial number of pellets }} \times 100$

\section{Scanning electron microscopy}

The surface morphology of the optimized coated pellets was examined using a scanning electron microscope. Scanning electron microscopy (SEM) analysis was performed using a Carl Zeiss Supra 5 scanning electron microscope (Germany). The pellet samples were mounted directly onto aluminum stubs and were sputter coated with a gold/palladium mixture for $1 \mathrm{~min}$ under an argon atmosphere. The coated pellets were mounted onto the stubs using double-sided adhesive tape. ${ }^{22}$

\section{Particle size distribution analysis}

The size distribution of the gastroretentive pellets was determined using a mechanical sieve shaker (Make-Kumar). A series of BSS standard stainless steel sieves of no. 8, 10, $22,36,44,60$, and 100 were arranged in order of decreasing aperture size. An accurately weighed amount of drug-loaded gastroretentive pellets from each batch was placed on the uppermost sieve. The sieves were shaken for $10 \mathrm{~min}$ and the material retained on each sieve was weighed separately. A graph of mean size vs \% weight retained was plotted to analyze pellet size distribution. ${ }^{23,24}$

\section{Physical characterization}

The micromeritic properties (bulk density, tapped density, Carr's index, Hausner's ratio, and angle of repose) of the floating pellets were determined. Friability of the pellets was determined using a USP friability test apparatus. Friability of the pellet formulations was determined as the percentage of weight loss after 200 revolutions of $6.5 \mathrm{~g}$ of the core pellets in a friabilator (Roche Friability Tester, India). The hardness of the pellets was determined using a digital hardness tester (Veego, India). ${ }^{25-27}$

\section{Pellet sphericity}

Pellet sphericity was determined by measuring the Feret diameter and perpendicular diameter of pellets by vernier caliper. From that aspect ratio was calculated (i.e. ratio of longest Feret diameter and its longest perpendicular diameter). ${ }^{28}$

\section{RESULTS AND DISCUSSION}

\section{UV spectrum of norfloxacin in $0.1 \mathrm{~N} \mathrm{HCl}$}

The $\lambda$ max of norfloxacin in $0.1 \mathrm{~N} \mathrm{HCl}$ was $273 \mathrm{~nm}$. The calibration curve of norfloxacin was obtained in $0.1 \mathrm{~N} \mathrm{HCl}$ at the respective $\lambda$ max value as indicated in Figure 1.

\section{Fourier transform infrared spectrum}

The IR spectrum of norfloxacin, Eudragit RL 100, and a physical mixture of norfloxacin and polymer (Eudragit RL 100) was obtained by fourier transform infrared (FTIR) (Figure
2). The interpretations of the IR frequencies were done and the absorption bands were consistent with the structure of norfloxacin and Eudragit RL 100. The FTIR spectra of the physical mixture indicated compatibility of norfloxacin and Eudragit RL 100. The FTIR spectra of pure drug showed functional peaks at 3600 to $3250,1492.95,2524.46,1267.27$, and $1614.47 \mathrm{~cm}^{-1}$. Eudragit RL 100 IR spectra showed peaks at 2920.32, 1720.56, and 1072.46, while the physical mixture showed peaks at 3491.27 , $3365.90,3012.91,2850.8,1745.64,1610.61,1456.30$, and 1269.20 $\mathrm{cm}^{-1}$ with negligible shift in wave number.

\section{Drug content}

The drug content in all pellet formulations was determined by UV spectroscopy and was found to be between $96.75 \pm 0.8 \%$ and $98.78 \pm 0.45 \%$, which indicated that the coating on the pellets also gives good reproducibility of drug content.

\section{Optimization of norfloxacin pellets}

To optimize the pelletization process MCC, PVP K30, and spheronizing speed were varied at different levels. Seventeen batches were prepared using a Box-Behnken design, and the aspect ratio and hardness of pellets were determined as response as indicated in Table 3.

The sphericity and hardness of pellets are essential properties to obtain effective coating. Spherical pellets provide a uniform surface, whereas sufficiently hardened pellets can withstand the mechanical stress during the subsequent coating process. The sphericity of pellets was determined in terms of aspect ratio. An aspect ratio value equal to unity indicates spherical

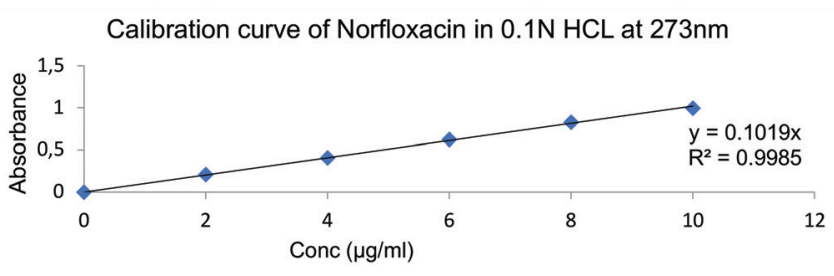

Figure 1. Calibration curve of norfloxacin in $0.1 \mathrm{~N} \mathrm{HCl}$ at $273 \mathrm{~nm}$

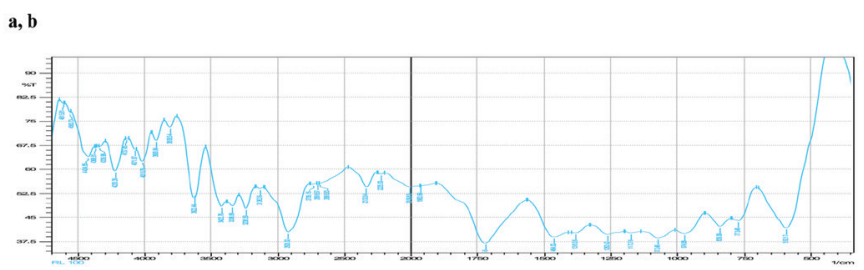

c

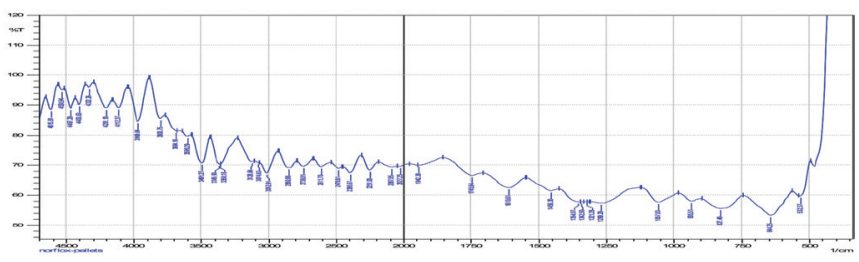

Figure 2. IR spectrum of (a) norfloxacin (b) Eudragit RL 100, and (c) physical mixture of norfloxacin and polymer (Eudragit RL 100)

IR: Infrared 
pellets. The response surface plots of aspect ratios obtained indicate that increasing the MCC amount and spheronizing speed yields pellets having an aspect ratio near to 1 , which is desirable, whereas increasing the amount of PVP K30 yields pellets having an aspect ratio greater than 1 . The response surface plots of hardness obtained indicate that with increasing amount of PVP K30 the hardness of pellets also increases, as indicated in Figure 3. From the results of the experimental design batch number B-4 was selected, having aspect ratio 1.1 and hardness 0.59 , for incorporation of $\mathrm{NaHCO}_{3}$ :HPMC K15M in different ratios and the subsequent coating process.

Regression equations of the fitted quadratic model:

Aspect ratio $(Y 1)=+1.41+0.036 * A-0.16 * B-0.013 * C-0.16 * A 2-$ $0.030 * B^{2}+0.018 * C^{2}-0.030 * A * B-0.038 * A * C+0.13 * B * C$.

Hardness $(Y 2)=+0.48-0.028$ * $A-0.055 * B+5.000 E-003$ * $C+0.068$ * $A^{2}+0.16$ * $B^{2}-0.081 * C^{2}-0.10 * A$ * $B-0.050$ * $A$ * $\mathrm{C}+0.023 * \mathrm{~B} * \mathrm{C}$.

Here A, B, and C are spheronizing speed, MCC, and PVP K 30 , respectively.

It was observed from the regression equation that the independent variable MCC has a negative effect on the aspect ratio ( $Y 1$ ). This proves that an increasing amount of MCC leads to a decrease in the aspect ratio, i.e. near to unity, which is desirable. On hardness (Y2) a positive effect of PVP K30 was observed. As the concentration of PVP K30 increases the hardness of pellets also increases.

\begin{tabular}{llllll}
$\begin{array}{l}\text { Table 3. Aspect ratio and hardness of experimental formulations } \\
\begin{array}{l}\text { Batch } \\
\text { number }\end{array}\end{array}$ & $\begin{array}{l}\text { Spheronizing } \\
\text { speed (rpm) }\end{array}$ & $\begin{array}{l}\text { Microcrystalline } \\
\text { cellulose }(\%)\end{array}$ & $\begin{array}{l}\text { Polyvinyl } \\
\text { pyrrolidone } \\
\text { K30 (\%) }\end{array}$ & $\begin{array}{l}\text { Aspect } \\
\text { ratio } \\
(\mathrm{mm})\end{array}$ & $\begin{array}{l}\text { Hardness } \\
\left(\mathrm{kg} / \mathrm{cm}^{2}\right)\end{array}$ \\
\hline B-1 & 850 & 25 & 4 & 1.90 & 0.72 \\
\hline B-2 & 750 & 35 & 6 & 1.16 & 0.77 \\
\hline B-3 & 850 & 30 & 6 & 1.41 & 0.47 \\
\hline B-4 & 950 & 35 & 6 & 1.15 & 0.59 \\
\hline B-5 & 850 & 30 & 6 & 1.41 & 0.47 \\
\hline B-6 & 850 & 35 & 8 & 1.16 & 0.42 \\
\hline B-7 & 850 & 25 & 8 & 1.39 & 0.56 \\
\hline B-8 & 950 & 30 & 4 & 1.26 & 0.37 \\
\hline B-9 & 850 & 35 & 4 & 1.14 & 0.50 \\
\hline B-10 & 850 & 30 & 6 & 1.41 & 0.47 \\
\hline B-11 & 850 & 30 & 6 & 1.41 & 0.47 \\
\hline B-12 & 850 & 30 & 6 & 1.41 & 0.47 \\
\hline B-13 & 750 & 30 & 8 & 1.36 & 0.65 \\
\hline B-14 & 750 & 25 & 6 & 1.24 & 0.60 \\
\hline B-15 & 950 & 25 & 30 & 1.35 & 0.83 \\
\hline B-16 & 750 & 30 & 6 & 1.09 & 0.41 \\
\hline B-17 & 950 & 85 & 0.41 \\
\hline & & 6 & 6 & & \\
\hline
\end{tabular}

Subsequently, $\mathrm{NaHCO}_{3}: \mathrm{HPMC} \mathrm{K} 15 \mathrm{M}$ was incorporated in the selected batch (B-4) in different ratios, i.e. 1:1, 1:2, and 2:1, to prepare three additional batches (B-18, B-19, and B-20). Drug release and floating studies were conducted on the prepared batches. The batch (B-19) containing $\mathrm{NaHCO}_{3}$ and HPMC K15M in the ratio of 1:2 yielded irregular shape and size pellets due to the higher amount of HPMC K15M, which was difficult to pass through the sieve, and the affecting spheronization process was not studied for drug release and floating behavior.

The plain norfloxacin pellet batch (B-4) showed $87.43 \%$ drug release within $1 \mathrm{~h}$. The norfloxacin pellet batch containing $\mathrm{NaHCO}_{3}$ and HPMC K15M in the ratios of 1:1 and 2:1 exhibited $84.19 \%$ in $4 \mathrm{~h}$ (B-18) and $92.42 \%$ in less than $2 \mathrm{~h}$ (B-20), respectively, as shown in Figure 4. The drug release in batch B-18 was sustained for $4 \mathrm{~h}$ but batch B-20 exhibited higher release in less than $2 \mathrm{~h}$, as it contained more sodium bicarbonate and the generated $\mathrm{CO}_{2}$ gas did not get entrapped in the polymer. The floating lag time for batches B-18 and B-20 was $8 \mathrm{~s}$ and $3 \mathrm{~s}$, respectively, in $0.1 \mathrm{~N} \mathrm{HCl}$. As the amount of sodium bicarbonate increases the floating lag time decreases. The total floating time of batches B-18 and B-20 was quite short, i.e. $4 \mathrm{~h}$ and $2 \mathrm{~h}$, respectively, as shown in Table 4 . In batch B-18 the time required to release above $80 \%$ of drug and total floating time were $4 \mathrm{~h}$. This type of behavior could be attributed to fact that once the HPMC was dissolved there was no polymeric membrane that could entrap the generated $\mathrm{CO}_{2}$ gas. Hence, batch B-18 containing $\mathrm{NaHCO}_{3}$ and $\mathrm{HPMC} \mathrm{K15M}$ in the ratio of 1:1 was further selected for coating with Eudragit RL 100 to design complete floating drug delivery system pellets. A Eudragit RL 100 coating was given in order to increase the total floating time and to sustain the release of norfloxacin. Three batches (B-21, B-22, and B-23) were prepared with Eudragit RL 100 coating with weight gain of $5 \%, 10 \%$, and $15 \%$ and evaluated for drug release and floating behavior.

The percentage drug release for batches B-21, B-22, and B-23 was $91.12 \%$ in 5 h, and $82.11 \%$ and $60.67 \%$ in 8 h, respectively, as shown in Figure 5. The drug release studies indicated that as the Eudragit RL 100 polymer coat increases the drug release decreases. The higher coat led to a thicker membrane over pellets, which retarded dissolution medium penetration and hence sustained drug release was obtained. The floating lag time for batches B-21, B-22, and B-23 was 290 s, 440 s, and $795 \mathrm{~s}$, respectively, in $0.1 \mathrm{~N} \mathrm{HCl}$. The total floating time of batches B-21, B-22, and B-23 was 5 h, 8 h, and 8 h, respectively,

Table 4. Floating studies of batches (B-18, B-20, B-21, B-22, and B-23)

\begin{tabular}{lll} 
Batch number & Floating lag time $(\mathrm{s})$ & Total floating time $(\mathrm{h})$ \\
\hline B-18 & $9 \pm 1$ & $4.07 \pm 0.75$ \\
\hline B-20 & $4 \pm 1$ & $1.89 \pm 0.105$ \\
\hline B-21 & $300 \pm 10$ & $4.99 \pm 0.1$ \\
\hline B-22 & $430 \pm 10$ & $8 \pm 0.05$ \\
\hline B-23 & $805 \pm 10$ & $7.85 \pm 0.15$ \\
\hline
\end{tabular}

Mean \pm standard deviation; $n=3$ 


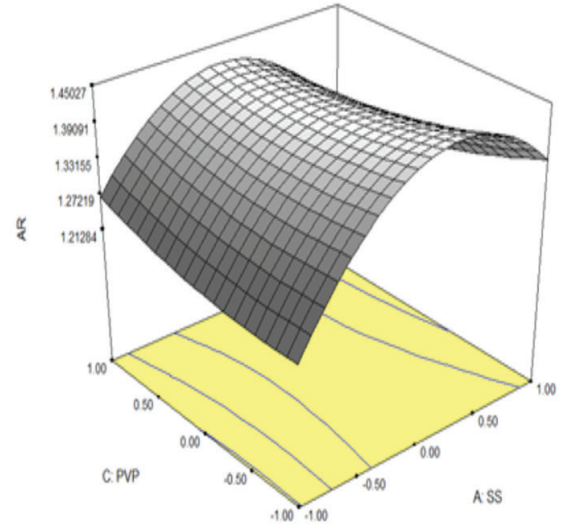

(a)

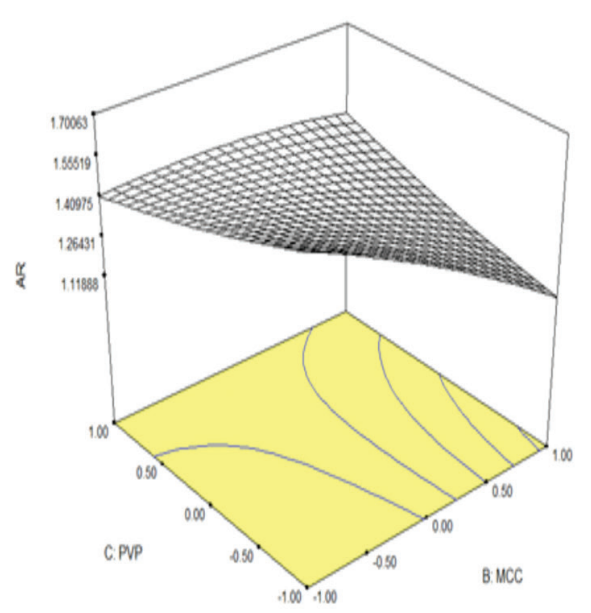

(c)

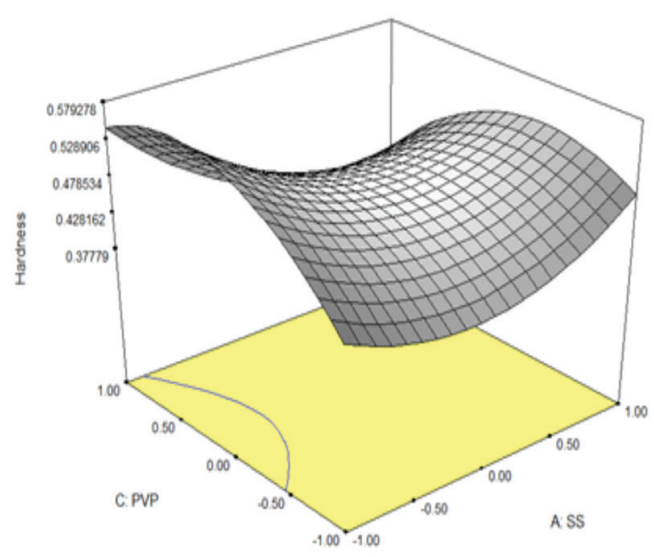

(e)

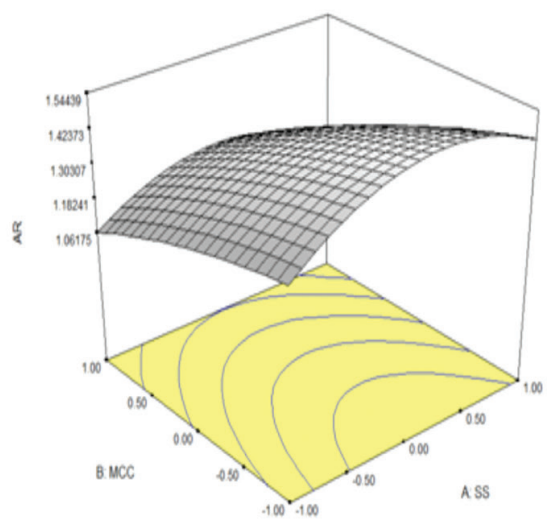

(b)

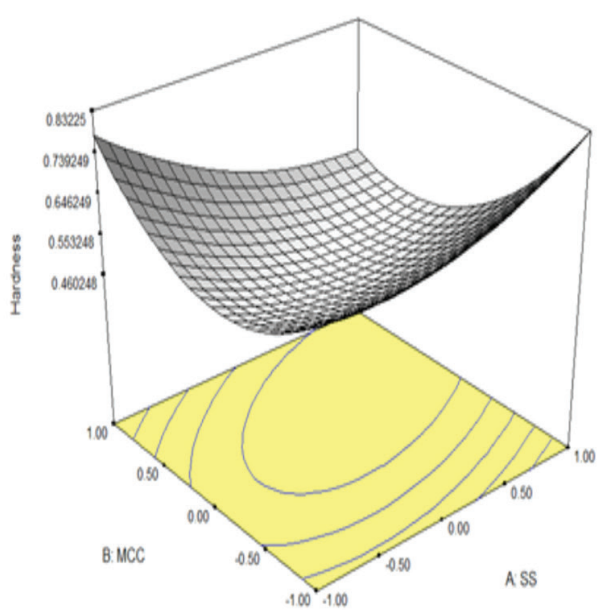

(d)

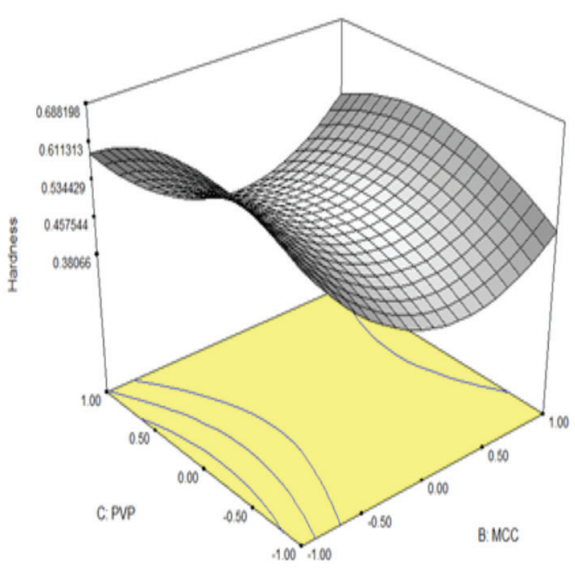

(f)

Figure 3. Response surface plot. (a, b, c) Aspect ratio (PVP vs SS, MCC vs SS, PVP vs MCC) respectively. (d, e, f) Hardness (MCC vs SS, PVP vs SS, PVP vs MCC) respectively 


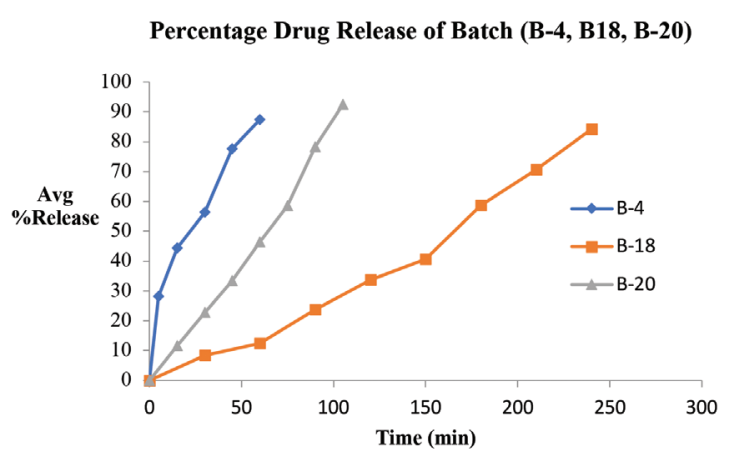

Figure 4. Percentage drug release of batch (B-4, B18, B-20) in $0.1 \mathrm{~N} \mathrm{HCl}$. Mean \pm standard deviation; $\mathrm{n}=3$

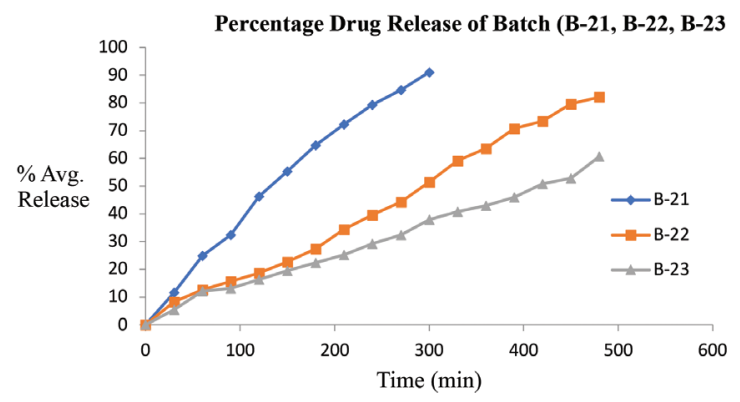

Figure 5. Percentage drug release of batch (B-21, B22, B-23) in $0.1 \mathrm{~N} \mathrm{HCl}$. Mean \pm standard deviation; $\mathrm{n}=3$

as shown in Table 4. Batches B-22 and B-23 had satisfactory floating ability, with $70 \%-90 \%$ of pellets remaining floating for up to $8 \mathrm{~h}$. The floating studies reveal that an increasing level of polymeric membrane coating increases floating lag time as well as total floating time. Due to the thicker polymer coat water penetration is retarded, which in turn delays $\mathrm{CO}_{2}$ gas generation, leading to increased floating lag time. However, once the $\mathrm{CO}_{2}$ gas is generated the increasing amount of polymer coat inhibits the permeation of gas out of the floating pellets system and maintains the buoyancy for a longer period.

Among the three complete floating drug delivery system pellet batches $\mathrm{B}-21, \mathrm{~B}-22$, and $\mathrm{B}-23$, batch $\mathrm{B}-22$ was found to be optimized based on the criteria of attaining minimum floating lag time (less than $10 \mathrm{~min}$ ), maximum total floating time, and maximum value of drug released in $8 \mathrm{~h}$.

\section{Scanning electron microscopy}

The surface morphology of the norfloxacin uncoated pellet batch (B-4) and coated pellet batch (B-22) was studied through SEM. The uncoated norfloxacin pellets' surface was wrinkled and rough, whereas the polymer-coated pellets showed smoother surfaces as indicated in Figures 6a and 6b.

\section{Particle size distribution analysis of pellets}

The particle size distribution analysis of pellets indicates a narrow size distribution in which most of the pellets are in the size range of $1000 \mu \mathrm{m}$ to $1200 \mu \mathrm{m}$, as shown in Figure 7 .

Physical characterization of pellets
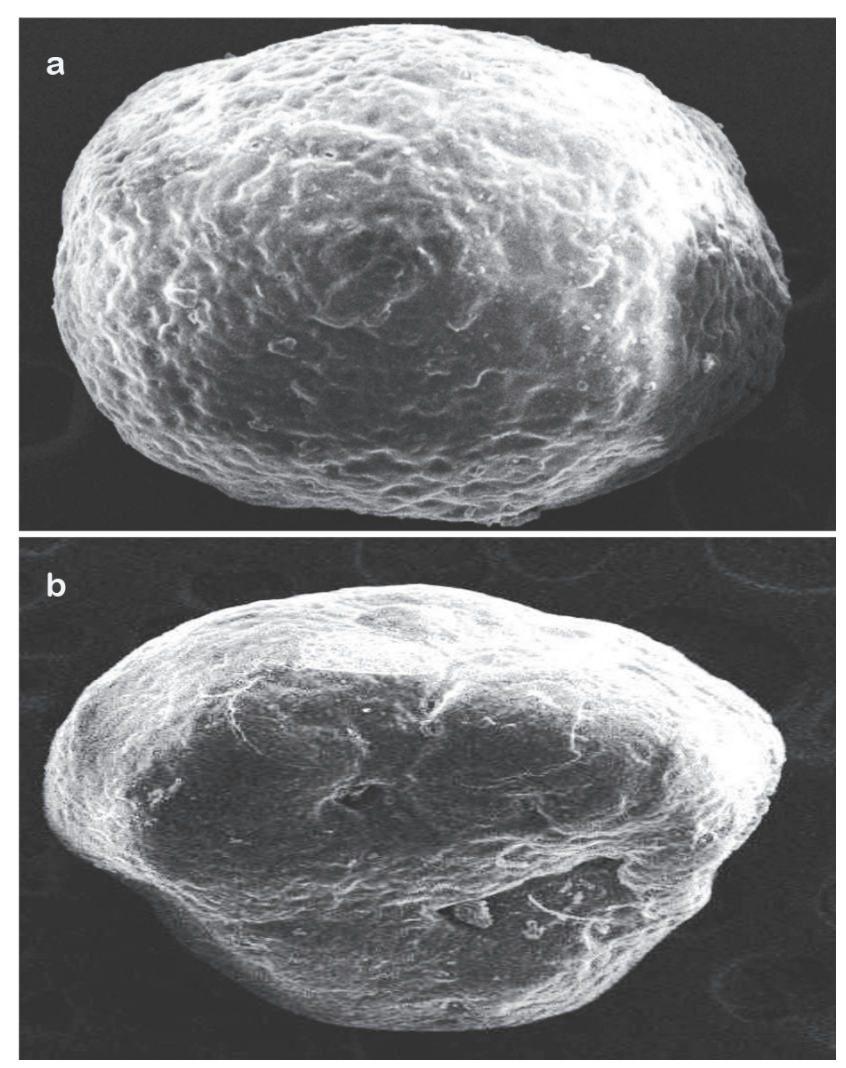

Figure 6. Scanning electron microphotographs of (a) uncoated norfloxacin pellets and (b) norfloxacin pellets coated with polymer at $100 \times$ magnification

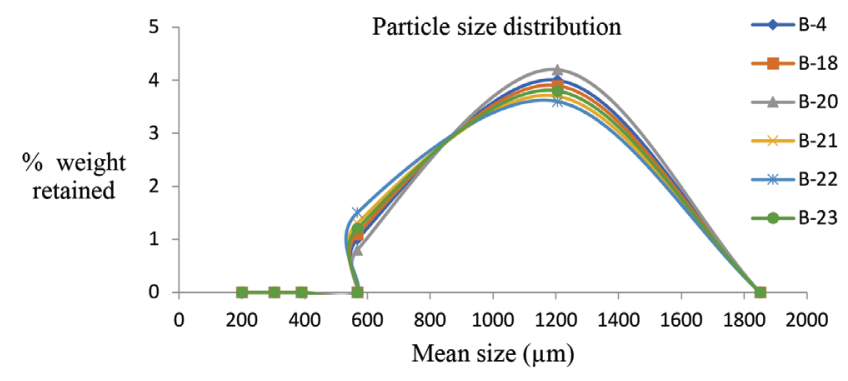

Figure 7. Particle size distribution curve

From the physical characterization of pellets, it was clearly observed that all the batches have excellent flow properties, with an angle of repose in the range $25.5 \pm 0.49^{\circ}$ to $28.02 \pm 0.30^{\circ}$ and Carr's index and Hausner's ratio in the range of $5 \%$ to $15 \%$ and $1.05 \pm 0.3$ to $1.14 \pm 0.3$, respectively (Table 5 ). The aspect ratio of pellets obtained was near to unity. Hardness and friability were in the range of $0.49 \pm 0.01$ to $0.61 \pm 0.01 \mathrm{~kg} / \mathrm{cm}^{2}$ and $0.17 \pm 0.52 \%$, respectively.

\section{CONCLUSIONS}

A gastroretentive multiparticulate drug delivery system for norfloxacin based on the gas generation technique was successfully designed and developed. The identification and purity of drug were affirmed by conducting infrared and UV spectroscopy studies. A 3-level, 3-factor, 17-run experimental Box-Behnken design was employed to optimize the norfloxacin 
Table 5. Physical characterization of pellet batches (B-4, B18, B-20, B-21, B-22, and B-23)

\begin{tabular}{lllllll} 
Batch number & Angle of repose $(\circ)$ & Carr's index $(\%)$ & Hausner's ratio & Aspect ratio $(\mathrm{mm})$ & Hardness $\left(\mathrm{kg} / \mathrm{cm}^{2}\right)$ & Friability $(\%)$ \\
\hline B-04 & $27.07 \pm 0.6$ & $14.85 \pm 0.65$ & $1.12 \pm 0.02$ & $1.17 \pm 0.02$ & $0.59 \pm 0.005$ & $0.30 \pm 0.1$ \\
\hline B-18 & $27.85 \pm 0.3$ & $9.23 \pm 0.66$ & $1.05 \pm 0.3$ & $1.14 \pm 0.02$ & $0.49 \pm 0.01$ & $0.48 \pm 0.2$ \\
\hline B-20 & $26.19 \pm 0.5$ & $12.13 \pm 0.63$ & $1.08 \pm 0.07$ & $1.13 \pm 0.01$ & $0.57 \pm 0.02$ & $0.52 \pm 0.09$ \\
\hline B-21 & $23.16 \pm 0.3$ & $7.51 \pm 0.37$ & $10.6 \pm 0.01$ & $1.14 \pm 0.03$ & $0.61 \pm 0.01$ & $0.35 \pm 0.02$ \\
\hline B-22 & $25.5 \pm 0.49$ & $5.62 \pm 0.42$ & $1.03 \pm 0.01$ & $1.18 \pm 0.005$ & $0.54 \pm 0.025$ & $0.16 \pm 0.01$ \\
\hline B-23 & $28.02 \pm 0.3$ & $11.62 \pm 0.36$ & $1.01 \pm 0.005$ & $1.09 \pm 0.06$ & $0.56 \pm 0.015$ & $0.21 \pm 0.1$ \\
\hline
\end{tabular}

Mean \pm standard deviation; $n=3$

pellets in terms of sphericity and hardness required to attain effective coating subsequently. The pellet batch obtained at spheronizing speed 950 rpm containing 35\% MCC with 6\% PVP $\mathrm{K} 30$ produced pellets with the desired sphericity and hardness. $\mathrm{NaHCO}_{3}$ and HPMC K15M in the ratios of 1:1, 1:2, and 2:1 (w/w) on a dry solid basis were incorporated into the norfloxacin pellets and they were further coated with Eudragit RL 100 using a fluidized bed processor to obtain weight gain of $5 \%, 10 \%$, and $15 \% \mathrm{w} / \mathrm{w}$. The floating ability and in vitro drug release of the system were dependent on the ratio of $\mathrm{NaHCO}_{3}$ to HPMC K15M and the percentage of Eudragit RL 100 polymer coat. As the amount of sodium bicarbonate increases floating lag time decreases. The drug release studies indicated that as the Eudragit RL 100 polymer coat increases the drug release decreases, producing sustained release of norfloxacin. The floating multiparticulate pellet batch containing $\mathrm{NaHCO}_{3}$ and $\mathrm{HPMC}$ K15M in the ratio of $1: 1$ with $10 \%$ Eudragit RL 100 coating showed the minimum floating lag time ( $<10 \mathrm{~min}$ ) and $82.11 \%$ average drug release in 8 h. The floating study reveals that $70 \%-90 \%$ of pellets remained floating for up to $8 \mathrm{~h}$. The significant result obtained with the study was that a floating multiparticulate drug delivery system based on the effervescent mechanism can be effectively employed for improvement of the bioavailability and therapeutic effect of drugs having poor absorption in the lower part of the gastrointestinal tract.

\section{ACKNOWLEDGEMENTS}

The author acknowledges Aarti Drugs Ltd, Mumbai, India for providing the gift sample of norfloxacin. The author is also thankful to Savitribai Phule Pune University for conducting the scanning electron microscopic studies.

Conflict of Interest: No conflict of interest was declared by the authors.

\section{REFERENCES}

1. Vo AQ, Feng X, Morott JT, Pimparade MB, Tiwari RV, Zhang F, Repka MA. A novel floating controlled release drug delivery system prepared by hot-melt extrusion. Eur J Pharm Biopharm. 2016;98:108-121.

2. Singh BN, Kim KH. Floating drug delivery systems: an approach to oral controlled drug delivery via gastric retention. J Control Release. 2000;63:235-259.
3. Lopes CM, Bettencourt C, Rossi A, Buttini F, Barata P. Overview on gastroretentive drug delivery systems for improving drug bioavailability. Int J Pharma. 2016;510:144-158.

4. Mandal UK, Chatterjee B, Senjoti FG. Gastro-retentive drug delivery systems and their in vivo success: A recent update. Asian J Pharma Sci. 2016;11:575-584.

5. Sharma AR, Khan A. Gastroretentive drug delivery system: an approach to enhance gastric retention for prolonged drug release. Int J Pharma Sci Res. 2014:5:1095-1106.

6. Narang N. An updated review on: floating drug delivery system (FDDS). Int J Applied Pharma. 2011; 3:1-7.

7. Thahera PD, Latha K, Shailaja T, Nyamathulla S, Uhumwangho MU. Formulation and evaluation of Norfloxacin gastro retentive drug delivery systems using natural polymers. Int Current Pharma J 2012;1:155-164.

8. Srivastava R, Chaturvedi D. Formulation, Characterization and Evaluation of Gastro-Retentive Floating Tablets of Norfloxacin hydrochloride. J. Pharmacy and Pharma Sci.2015:33-38

9. Guguloth M, Bomma R, Veerabrahma K. Development of Sustained Release Floating Drug Delivery. PDA J. Pharm Sci Technol. 2011;65:198206

10. Oliveira PR, Bernardi LS, Strusi OL, Mercuri S, Segatto Silva MA, Colombo P. Sonvico F. Assembled modules technology for site-specific prolonged delivery of norfloxacin. Int J Pharm. 2011;405;90-96.

11. Bomma R, Naidu RS, Yamsani M, Veerabrahma K. Development and evaluation of gastroretentivenorfloxacin floating tablets. Actapharma. 2009;59:211-221.

12. Bhattacharya SA, Prajapati BG. Formulation, design and development of ciprofloxacin hydrochloride floating bioadhesive tablet. e-J Sci Tech. 2017;12;40-70.

13. Rajaiya P, Mishra R, Nandgude T, Poddar S. Solubility and dissolution enhancement of albendazole by spherical crystallization. Asian $\mathrm{J}$ Biomedical Pharma Sci. 2016;6:9-14.

14. Nandgude T, Bhise K. Characterization of Drug and Polymers for Development of Colon Specific Drug Delivery System. Asian J Biomedical Pharma Sci. 2011;1:17-21.

15. Parmar S, Mishra R, Shirolkar S. Spherical agglomeration for Solubility and Dissolution Enhancement of Simvastatin, Asian J Pharm Clinical Res. 2016;9:65-72.

16. Nandgude T, Saifee M, Bhise K. Formulation and evaluation of fastdisintegrating tablet of Diphenhydramine Tannate. Asian J Pharma. 2006;1:41-45. 
17. Amrutkar PP, Chaudhari PD. Design and in vitro evaluation of multiparticulate floating drug delivery system of zolpidem tartarate. Colloids Surf B Biointerfaces. 2012;89:182-187.

18. Katakam VK, Reddy S, Somagoni JM, Panakanti PK, Yamsani MR. Design and Evaluation of a Novel Gas Formation-Based Multiple-Units as a Biphasic Gastro-Retentive Floating Drug Delivery System for Alfuzosin Hydrochloride. Research and Reviews. J Pharmacy Pharma Sci. 2013;2:33-46.

19. Zhang C, Xu M, Tao X, Tang J, Liu Z, Zhang Y, Lin X, He H, Tang X. A floating multiparticulate system for ofloxacin based on a multilayer structure: In vitro and in vivo evaluation. Int J Pharm. 2012;430:141-150.

20. Pagariya TP, Patil SB. Development and optimization of multiparticulate drug delivery system of alfuzosin hydrochloride. Colloids Surf B Biointerfaces. 2013;102:171-177.

21. Kendre PN, Chaudhari PD. Effect of polyvinyl caprolactam-polyvinyl acetate-polyethylene glycol graft copolymer on bioadhesion and release rate property of eplerenone pellets. Drug Dev Ind Pharm. 2017;43:751761.

22. Chakravarthy KK, Younus M, Shaik S, Pisipati SV. Formulation and Evaluation of Enteric Coated Pellets of Omeprazole. Int J Drug Dev Res. 2012;4;257-264.
23. Tubati VP. Murthy GK, Rao SS. Formulation Development and Statistical Optimization of Ivabradine Hydrochloride Floating Pulsatile Microspheres Using Response Surface Methodology. Asian J Pharm. 2016;10:1-11

24. Patil SM, Mishra RV, Shirolkar SV. Development and Evaluation of Sustain Release Simvastatin Pellets. Res J Pharm Techn. 2017;10:24672473.

25. Diggikar SS, Nandgude TD, Poddar SS. Formulation of Modified Release Pellets of Montelukast Sodium. Res J Pharm Techn. 2018;11:31-37.

26. Muley s, Nandgude T, Poddar S. Extrusion-spheronization a promising pelletization technique: In-depth review. Asian J Pharma Sci. 2016;11:684-699.

27. Muley SS, Nandgude T, Poddar S. Formulation and Optimization of Lansoprazole Pellets Using Factorial Design Prepared by ExtrusionSpheronization Technique Using Carboxymethyl Tamarind Kernel Powder. Recent Pat Drug Deliv Formul. 2017;11:54-66.

28. Raval MK, Ramani RV, Sheth NR. Formulation and evaluation of sustained release enteric-coated pellets of budesonide for intestinal delivery. Int J Pharm Investig. 2013;3:203-211. 